\title{
Stemming the Flood: the Censorship of Translated Popular Fiction in Fascist Italy
}

DOI:

10.1080/0907676X.2018.1444646

\section{Document Version}

Accepted author manuscript

Link to publication record in Manchester Research Explorer

\section{Citation for published version (APA):}

Rundle, C. (2018). Stemming the Flood: the Censorship of Translated Popular Fiction in Fascist Italy.

Perspectives: Studies in Translatology, 26(6), 1. https://doi.org/10.1080/0907676X.2018.1444646

\section{Published in:}

Perspectives: Studies in Translatology

\section{Citing this paper}

Please note that where the full-text provided on Manchester Research Explorer is the Author Accepted Manuscript or Proof version this may differ from the final Published version. If citing, it is advised that you check and use the publisher's definitive version.

\section{General rights}

Copyright and moral rights for the publications made accessible in the Research Explorer are retained by the authors and/or other copyright owners and it is a condition of accessing publications that users recognise and abide by the legal requirements associated with these rights.

\section{Takedown policy}

If you believe that this document breaches copyright please refer to the University of Manchester's Takedown Procedures [http://man.ac.uk/04Y6Bo] or contact uml.scholarlycommunications@manchester.ac.uk providing relevant details, so we can investigate your claim.

\section{OPEN ACCESS}


Rundle, Christopher (2018) "Stemming the flood: the censorship of translated popular fiction in Fascist Italy", Perspectives. DOI: 10.1080/0907676X.2018.1444646. (CThis Author Accepted Manuscript (AAM) may not be copied or distributed in any shape or form without written permission from the author.

\title{
Stemming the flood: the censorship of translated popular fiction in Fascist Italy
}

Christopher Rundle

${ }^{a}$ Department of Interpreting and Translation, University of Bologna, Forli Campus, Italy; ${ }^{b}$ School of Arts Languages and Cultures, University of Manchester, Manchester, UK

\begin{abstract}
In this article I will show how the hostility towards translation in Italy during the Fascist regime, and in particular in the 1930s and the early 1940s, was principally motivated by a hostility towards popular fiction and its dramatic impact on the Italian publishing industry. I also want to show how, when the regime eventually intervened against translation, its main objective was to restrict the flow of popular fiction and protect the masses from its perceived harmful influence. In conclusion, I shall argue that the history of translation and of popular fiction in this period are inextricably linked and that an examination of this theme can provide a significant insight into the evolution of Fascist cultural policy.
\end{abstract}

Keywords: translation, censorship, popular fiction, crime fiction, fascism, Italy

\section{Introduction}

In this article I want to show how the hostility towards translation in Italy during the Fascist regime, and in particular in the 1930s and the early 1940s, was principally motivated by a hostility towards popular fiction. In my earlier research on translation in Fascist Italy I have recounted in some detail how the regime's attitudes towards translation evolved in line with its increasingly xenophobic and racist policies, and I have recounted how it only intervened relatively late with specific censorship measures aimed at translations (Rundle, 2010). My purpose in this article is to try and establish the extent to which the frequent complaints that Italy was being subjected to an 'invasion of translations' were actually a reaction to the impact of popular novels, especially crime novels, and that translation and popular fiction were frequently conflated in the hostile rhetoric of the day as if they were one and the same phenomenon - both symptoms of the same ill. I also want to show how, when the regime finally intervened against translation, its main objective was to restrict the flow of popular fiction and protect what it perceived as the vulnerable masses from the harmful influence of a genre that it saw as decadent and corrupting.

\section{Establishment hostility towards translation}

As far as current research has been able to establish, the regime took no concrete action against translations until the late 1930s, in the wake of the introduction of official anti-Semitism (Billiani, 2007; Bonsaver, 2007; Fabre, 2007; Rundle, 2010). We shall return to these measures later, but first I want to look at the two campaigns that were conducted in the press and in sector journals by parts of the literary and cultural establishment against what was perceived as an 'invasion of translations' and consider the role that popular fiction played in the debate.

The backdrop against which these campaigns took place was one in which Italian publishing was undergoing a significant transformation. It was evolving from a more artisan model of small publishing houses catering for a select readership with expensive, high quality editions of high-brow literary works and with relatively limited print runs, to an industrial model of large publishing houses offering cheap mass-produced popular novels that appealed to a new and much wider audience (Tranfaglia \& Vittoria, 2000, Chapter 4). This commodification of literature was a process that was taking place throughout the 
Rundle, Christopher (2018) "Stemming the flood: the censorship of translated popular fiction in Fascist Italy", Perspectives. DOI: 10.1080/0907676X.2018.1444646. (CThis Author Accepted Manuscript (AAM) may not be copied or distributed in any shape or form without written permission from the author.

Western world, of course, with the rise of a large white-collar class with some disposable income and a desire for entertaining reading matter in the form of 'pulp' editions, paperbacks and magazines; a new market, in which the tastes and interests of women played an important part (Nottola, 2012; Barrale, 2012, 2015), and that was also abetted by the success of other forms of popular culture such as radio and, in particular, the cinema (Tranfaglia \& Vittoria, 2000, p. 300, pp. 311-12). But perhaps in no other country did translation play such a significant role in these changes as in Italy; for it was principally translated titles that fed the public's growing appetite for light fiction (Rubino, 2002; Rundle, 2010).

The result was a long period of conflict between the publishers on the one hand, represented by the Italian Publishers Federation [Federazione nazionale fascista degli editori industriali], and writers and intellectuals on the other, led by the Authors and Writers Union [Sindacato nazionale fascista degli autori e scrittori]; where the publishers were forced to defend themselves against accusations of flooding the market with unworthy literature.

\section{(i) The campaigns against translations}

Although there had been some complaints in the 1920s about poorly executed translations of low-quality literature and their potential impact on the Italian language and reading public, these were mostly restricted to literary journals and remained within the confines of what was essentially a literary and aesthetic debate (Billiani, 2007; Bonsaver, 2007). But in the late 1920s and 1930s hostility towards translation became more widespread and took on a more political and ideological character.

This hostility was a combination of a genuine sense of alarm at a form of competition that many writers felt unable to deal with, a competition that was real, not imagined, and which really did mark a sea change in Italian publishing; and also an ideological objection to the fact that Italy was so receptive to foreign literature. For, just as the literary establishment began to understand the significant impact that the many new series of popular fiction were having on the Italian market, the Index Translationum was launched in 1932. The Index was published by the International Institute of Intellectual Cooperation in Paris, an agency under the aegis of what was then the League of Nations, and it made it possible for the first time to compare statistics on translation between different nations.

These statistics became the focus of two campaigns against translations, the first in the period 1929-34 and the second in 1936-38. They made it clear that Italy was publishing more translations than any other country in the world. Furthermore, it soon became apparent that Italy, as well as being the most receptive country, was one of the least successful in exporting its own literature in the form of translations into other languages. Italy's cultural trade balance [bilancio culturale], to adopt a phrase frequently used at the time, was consistently negative, while Germany - the country against which Italy tended to measure its own success - enjoyed a healthy positive balance (see Barrale in this issue). While the figures available for this period contain a lot of gaps, the difference that emerges between Germany and Italy is marked enough to make it clear why this particular piece of data was so disturbing to the Italian literary establishment: Italy's translation 'deficit' was on average -815 translations a year, while Germany translation 'surplus' was on average +1181 a year (for a detailed breakdown and discussion of these statistics, see Rundle, 2010, Chapter 2).

The ideological implications of these statistics were significant. At a time when Italy was supposed to be undergoing a cultural revolution at home and expanding its cultural influence abroad, in line with its 
Rundle, Christopher (2018) "Stemming the flood: the censorship of translated popular fiction in Fascist Italy", Perspectives. DOI: 10.1080/0907676X.2018.1444646. (CThis Author Accepted Manuscript (AAM) may not be copied or distributed in any shape or form without written permission from the author.

'eternal role as disseminator rather than receiver', ${ }^{1}$ the figures on translation instead showed a country with a marked taste for foreign literature and one that was strikingly unsuccessful in exporting its own. This was a political embarrassment and also placed the publishers in a difficult position. On the one hand they understandably wanted to continue exploiting an expanding market, on the other they did not want to be seen to be lukewarm in their support for the cultural and political project of the regime.

The embarrassment these figures caused the publishers became even more acute when the League of Nations imposed sanctions on Italy because of its invasion of Ethiopia in 1935. There followed a period of intense nationalism and xenophobia in Italy, with a particular hostility reserved for 'perfidious Albion' given that Mussolini believed that it was the British who refused to accept Italy into the exclusive coterie of the colonial powers. This wave of public indignation was then harnessed by the regime's artfully orchestrated campaign of autarky. At a time when it became a political imperative to reduce all foreign imports to an absolute minimum those members of the cultural establishment who were hostile to translations launched a second campaign, led by the Authors and Writers Union and the Futurist poet F. T. Marinetti. They were soon calling for the application of a cultural autarky, and for restrictive importation barriers to be imposed on translations. In this very tense political climate, it became increasingly difficult for the publishers to defend themselves from the accusation of unpatriotically favouring foreign over domestic products.

It is interesting to note those statistics which, rather surprisingly, were not used in this argument. For example, the fact that English was regularly the most frequent source language for the translations published was not raised, not even when any form of perceived Anglophilia became politically unacceptable after the sanctions. Neither was the fact that, as well as being numerically more frequent, translations also made up a greater proportion of Italy's overall book production than other countries; something that could have been used against the publishers by their detractors.

It is also interesting to note that the regime itself intervened very rarely in this debate and took no concrete action. One can only speculate on the reasons for this. While the regime undoubtedly disapproved of Italy's marked receptivity, it is probable that it did not want to damage the publishers, a successful industry conducted by a loyal federation that was undergoing a process of modernisation that the regime approved of. It is also possible that seeing the literary establishment being shaken up and forced to adapt to these market changes may have appealed to the ambition of the Fascist party to force the intellectual elite to come down from its pedestal. In the words of Mussolini:

Fascism [...] dislikes the ivory towers of pure intellectualistic speculation which all too often conceals an incurable aridity of the spirit. $^{2}$

As we shall see, this policy of non intervention would only change in 1937 when the regime first started to take an active interest in the issue of translation.

\footnotetext{
${ }^{1}$ Alessandro Pavolini, the then Minister for Popular Culture, in a speech given at the annual inauguration of the ItaloGermanic Association. Undated. ACS, MCP, b.103, f. 'Discorsi ed articoli del Ministro Pavolini'. All translations from the Italian are mine.

${ }^{2}$ From a speech given by Mussolini to the first national assembly of the Confederation of Professionals and Artists [Confederazione nazionale fascista professionisti e artisti] in Rome in October 1932. Reprinted in "Il discorso del Duce" [The Duce's speech], in Atti del Sindacato Fascista degli Ingegneri di Torino e del Sindacato Regionale Fascista degli Architetti del Piemonte, 6 (10), 1932, pp. 11-13. DRPT.
} 
Rundle, Christopher (2018) "Stemming the flood: the censorship of translated popular fiction in Fascist Italy", Perspectives. DOI: 10.1080/0907676X.2018.1444646. (CThis Author Accepted Manuscript (AAM) may not be copied or distributed in any shape or form without written permission from the author.

\section{(ii) The terms of the debate}

To return to the terms of the debate during these two campaigns: the publishers understandably tried to minimize the 'translation problem' by saying that it was only in the area of popular literature that there was a translation problem and in all other areas Italy was holding its own and living up to its prominent position in the world. But this defensive argument privileged cultural prestige over economic impact and did not take into account the huge sales that translated popular fiction was enjoying. An example of this is provided by the vice president of the Publishers Federation, Antonio Vallardi, who said to a General Assembly in May 1934:

$[\ldots]$ it seems to us that the [translation] phenomenon is not so alarming in Italy as it appears to some; especially if we consider that [..] it is a phenomenon which principally concerns popular literature, while in the sciences and in art, in historical and juridical disciplines, in philosophy and in pedagogy, Italy has almost completely freed itself from any foreign domination. ${ }^{3}$

What is striking here is the implicit (and damaging) admission that, as far as popular literature was concerned, Italy was being 'dominated' by foreign products. It also makes it clear that it was this area where the publishers felt most on the defensive. The extension to this argument was that the solution to the problem was not to curb popular fiction, which the public evidently had an appetite for, but for Italian authors to rise to the challenge and provide domestic fiction that could sell. This was the president of the Publishers Federation, Franco Ciarlantini's suggestion in an article he wrote in 1938:

There is much talk of a crisis in Italian books, not so much these days because of poor sales, but because of the lack of works, especially of popular literature, that can keep pace with foreign works of this genre. (Ciarlantini, 1938, p. 254)

Predictably, these arguments did not cut much ice with the writers and other intellectuals who objected loudly to the invasion of low quality literature they saw taking place via translations:

Translations into Italian should be restricted to works of real artistic, scientific or political value; while works of so-called popular literature should be rejected without mercy as they constitute a constant threat for the education and good taste of our people. ${ }^{4}$

This was by far the most dominant view of the problem of translated popular fiction. While cultural exchange was both acceptable and desirable when it came to the sciences, philosophy and 'high' literature, the kind of low quality works that the publishers were favouring were perceived as a moral threat to the mass audience they catered for and were seen to be corrupting the tastes of Italian readers, making it increasingly difficult for Italian authors to find a market for their more 'refined' literary production. Even Giuseppe Bottai, the Minister for Education [Ministro dell'educazione nazionale] who, setting aside his unflinching adherence to official racism, is generally considered to have been one of the more open-minded leaders of the regime, expressed doubts about the negative influence of popular literature and, anticipating what his colleagues at the Ministry for Popular Culture [Ministero della cultura popolare] would shortly do, equated the dangers of this genre with the danger posed by Jewish culture:

\footnotetext{
${ }^{3}$ Reported in the Publishers Federation's journal, Giornale della libreria 47(18), 5 May 1934, pp.109-16.

${ }^{4}$ From an unsigned editorial in the journal L'Orto 5(04-05), July/October 1935, p. 39.
} 
Rundle, Christopher (2018) "Stemming the flood: the censorship of translated popular fiction in Fascist Italy", Perspectives. DOI: 10.1080/0907676X.2018.1444646. (CThis Author Accepted Manuscript (AAM) may not be copied or distributed in any shape or form without written permission from the author.

Every character to emerge from a Jewish pen talmudizes, which is to say that he interprets as he wanders, and he errs as he interprets, moods, impulses, desires and passions. Let me not be thought ruthless, then, if I suggest that in this field of popular and children's literature we should put aside all indulgence. ${ }^{5}$

This, however, was written in early 1939 when official anti-Semitism had been introduced and every issue tended to be interpreted and discussed in terms of race. Bottai also mentions children's literature together with popular literature. This is both because, as Minister of Education, he felt that the well-being of children was his special responsibility and because the regime was principally concerned with monitoring and moulding those sections of society which it saw as especially susceptible to external influence and in need of protection: children and the less well-educated masses who read so many popular novels.

The specific genre which seems to have represented all the worst ills and dangers of popular literature was crime fiction (to this day commonly called romanzi gialli [yellow novels] in Italy because of the iconic yellow covers of the first dedicated series to appear in Italy, Mondadori's I libri gialli). As we shall see, this would be the one genre specifically targeted by the regime when it eventually took action against translations. Of all the popular genres, crime fiction was seen as the most morally corrupting because it was filled with negative role models and encouraged an unhealthy interest in social deviance. Whenever there were complaints about the moral dangers of popular fiction, crime novels were usually the prime target, sometimes with almost comical levels of anxiety and indignation:

[...] the reader who wishes to immerse himself in crime, eroticism, and psycho-sexual complications, can go and buy the French, American, and English novels that are rife in all the bookshops of the kingdom. ${ }^{6}$

To which the publishers could only respond by saying that they were also in business to make money, and that they would do so by publishing crime novels if that was what the public wanted to read (Marrubini, 1938, p. 18).

In more sober terms, when the writer Ettore Valerio, among others, proposed measures to limit the 'invasion' of foreign works into Italy, he suggested that a ministerial commission be created in order that it might apply some form of quality control and impose a principle of reciprocity 'especially where narrative literature and crime fiction are concerned'.

As we shall see in the following section, the regime would eventually adopt some of these measures: in particular a commission designed to tackle the book market, and specific restrictions on crime fiction. But first it is worth mentioning those few who intervened in the debate with less alarmist tones and argued that popular fiction, with its high print runs and low costs, was the only means to enhance the diffusion of books in Italy and increase the number of people who read.

\footnotetext{
${ }^{5}$ From an unsigned editorial entitled "Bonifica libraria" [Purging of Books] in the journal Critica Fascista, 1 January 1939. Thought to have been written by Bottai who was editor of the journal and would certainly have approved it. Cited in Santoni (2010, p. 50).

${ }^{6}$ From an article by Giuseppe Villaroel entitled "Do ut des" and published in the journal Augustea, 15 December 1937. Cited in Marrubini (1938, p. 17).

${ }^{7}$ From a speech entitled "La diffusione del libro straniero in Italia" [The diffusion of foreign books in Italy], given at the III National Congress of the Authors and Writers Union, in Naples 11-13 October 1936. Reprinted in the union's own journal, Autori e scrittori 1(6-7), Oct-Nov 1936, pp. 2-29.
} 
Rundle, Christopher (2018) "Stemming the flood: the censorship of translated popular fiction in Fascist Italy", Perspectives. DOI: 10.1080/0907676X.2018.1444646. (CThis Author Accepted Manuscript (AAM) may not be copied or distributed in any shape or form without written permission from the author.

Arnoldo Mondadori, Italy's most prolific publisher of translations, including the Libri gialli crime series, and without doubt one of the most important Italian publishers of the $20^{\text {th }}$ century (Decleva, 1993), made this point in his own defence when he was accused of being too 'industrialized' (i.e. of publishing too much popular fiction) during one of the many conferences that were held at the time on the 'Diffusion of books', in Florence in June 1937. With his characteristically direct style Mondadori replied that he was industrialized, but in a positive way and by providing works that people actually wanted to read, while providing work for a lot of families. He also said that the State should provide the publishing sector with the same measures of support that it was providing theatre and cinema (in recognition of what he considered to be its equal importance as a mass form of culture) and that it was up to the publishers to worry about how to publish books and improve their diffusion'.8

The Education Minister, Bottai, also associated popular literature with other forms of mass entertainment in an editorial entitled 'Books and the culture of the people' [Il libro e la cultura del popolo]. He was contributing to a long-standing discussion on the 'book crisis' that Italy was perceived to be suffering from (Tranfaglia \& Vittoria, 2000, pp. 242-48; Pedullà, 1997, pp. 357-73) in which he argued that the only way to get people to read was to accept the changes that were taking place in society and provide them with the kind of literature that they wanted to read, without abandoning the aim of improving them as well. So, in effect, implicitly admitting, along with Mondadori, that there could be a positive form of popular literature:

We should address the readership and consider its social composition; and ask ourselves whether the relationship between books and readers has not changed so much that new approaches have to be found, different to those that we have considered valid until now. [...] the book is no longer the cultural reference point of our society. [...] It is not by denigrating the impact of radio and cinema that we can save the book. Quite the contrary. We must cultivate the intellectual stimulation that radio, cinema and even sport undoubtedly provoke in the people like a young bud that can then flower into a profound awareness of the importance of books as the crowning achievement of their moral and intellectual growth. Only when books will seem the ideal conclusion, to be approached not against but through the other cultural channels, will the book crisis come to an end. (Bottai 1937)

In this passage Bottai puts his finger on one of the essential dilemmas of the Fascist cultural project: that is, how to create a popular culture that was both Italian (i.e. not subservient to foreign influence) and retained the core values of Fascism but did not descend into the kind of amorality that they felt was being transmitted via much of the translated popular fiction that the public had obviously developed a taste for.

\section{The institutional response}

We come now to the regime's response to this perceived invasion of translations. What I want to highlight here is how the regime's attitudes to popular literature and the evolution of its censorship policies are very closely linked. I will argue that when the regime did, eventually, intervene against translations, it was with the intention of curbing the influx of translated popular fiction. Popular fiction became a problem both because it was the source of the embarrassing statistics on translation, and because it would come to be seen in an increasingly alarmist light following the introduction of official racism.

\footnotetext{
${ }^{8}$ The accusation was reported in Critica Fascista, 15 June 1937, and Mondadori replied with a letter in Critica Fascista, 1 July 1937. The discussion at this conference is also discussed in Fabre (1998, pp. 58-59) and Santoni (2010, p. 19).
} 
Rundle, Christopher (2018) "Stemming the flood: the censorship of translated popular fiction in Fascist Italy", Perspectives. DOI: 10.1080/0907676X.2018.1444646. (CThis Author Accepted Manuscript (AAM) may not be copied or distributed in any shape or form without written permission from the author.

\section{(i) The censorship of books}

While the regime early on established tight preventive control over all forms of periodical publication and other forms of mass entertainment such as theatre and cinema, it was only in 1934 that it first introduced preventive measures in the censorship of books. ${ }^{9}$ It is significant that it was a popular novel that provoked a change in Fascist policy. The novel Sambadù amore negro by the Italian writer Maria Volpi (writing under the pseudonym of Mura) was published that year by the prominent publisher Rizzoli as a supplement to its illustrated magazine Novella. It came with a bold cover illustration which showed a black man in a Western suit embracing a swooning white woman and it told the tale of an ill-fated marriage between an African engineer and a young Italian widow. ${ }^{10}$ Mussolini came into possession of a copy of the novel and he was furious. At a time when preparations were already being made for Italy's invasion of Ethiopia the following year, he felt it was totally unacceptable that a cover apparently celebrating interracial love could have been published without any objections being made. Practically overnight, Mussolini gave instructions for a new system of preventive censorship of books to be instituted. These measures were not enshrined in law but were officialised by means of a circular that was sent to all Police Prefects. ${ }^{11}$ They made it obligatory for the publishers to send in three copies of every book printed before it was distributed or sold. One of these copies would stay with the local prefecture, one would be sent to the General Directorate for Public Security [Direzione generale della pubblica sicurezza], and one would be sent to the Prime Minister's Press Office. The Press Office was the precursor of the future Ministry for Press and Propaganda [Ministero per la stampa e la Propaganda] and was effectively the state censorship office of the time. ${ }^{12}$

The subtlety of this system lay in the fact that it allowed the regime to continue to state that there was no preventive censorship in Italy because, technically speaking, publishers were free to print what they wanted; they just had to notify the authorities before they could actually sell the books. Furthermore, the persuasive effect on the publishers of knowing that their books were being sent in to be checked was usually enough to ensure that nothing too offensive was published. When mistakes were made the book would be withdrawn from publication and in some cases impounded and destroyed. In some milder cases, the publisher was told that no further copies could be printed but existing copies could be allowed to sell out (Rundle, 2010, p. 94 n.43).

Clearly this system involved a high degree of financial risk for the publishers as they would only find out if a book was banned after they had gone to the expense of printing it. In order to try and alleviate this

\footnotetext{
${ }^{9}$ For more details on the Fascist system of censorship see Bonsaver (2007), Bonsaver \& Gordon (2005), Dunnett (2002), Fabre (1998; 2007), Rundle (2000; 2010), Talbot (2007).

${ }^{10}$ The cover is reproduced in Bonsaver (2007, p. 98); Fabre (1998, p. 437); and Gadducci, Gori \& Lama (2011, p. 118). A good quality image of the cover can also be viewed on the following webpage: https://mistergiuseppe.wordpress.com/2016/04/10/i-romanzi-di-novella/ (last accessed 16 December 2017).

${ }^{11}$ Circular No. 442/9532, dated 3 April 1934, and signed by Mussolini in his capacity as Interior Minister. A copy of the circular can be found in ACS, MI, DGPS, DAGR, Massime, b. S4 (provv.), f. S4 A 1/1. 'Disciplina delle pubblicazioni. Circolari'. This very significant circular, which marks a turning point in the Fascist censorship of books, was discovered by Giorgio Fabre and its history is reconstructed in great detail in his book (Fabre 1998, pp. 22-28). Bonsaver (2007, pp. 95-102) has also discussed this event in some detail and he makes the interesting observation that Mussolini cannot have read the story or he would have realised that, contrary to the impression created by the cover, the novel was very much a cautionary tale against interracial marriage.

${ }^{12}$ The Ministry for the Press and Propaganda was later renamed Ministry for Popular Culture. See Rundle (2010, pp. 12-20) for a detailed reconstruction of the evolution of the state censor.
} 
Rundle, Christopher (2018) "Stemming the flood: the censorship of translated popular fiction in Fascist Italy", Perspectives. DOI: 10.1080/0907676X.2018.1444646. (CThis Author Accepted Manuscript (AAM) may not be copied or distributed in any shape or form without written permission from the author.

difficulty, the regime agreed to allow publishers to send in proofs to be checked, so that if there were any issues they could intervene on specific pages without having to scrap the entire book, and it agreed to provide publishers with the motivation for any bans so that similar problems could be avoided in future; a testimony to the generally cordial and collaborative relationship that existed between publishers and the censor (Rundle 2010, pp. 147-8). The regime even went to the length, on occasion, of compensating publishers for the financial damage incurred by a ban, though this probably only occurred with those publishers who enjoyed particularly close relations with the censor's office (Bonsaver, 2007, p. 224; Rundle 2010, p. 202).

\section{(ii) The censorship of translations}

It is important to underline that for most of the duration of the regime there was no specific procedure for translated books. Translations were simply monitored using the same methods and parameters as those used for Italian books. It was only in 1937 that the regime first introduced measures that were specifically aimed at translations, and only in 1940 that it introduced the first limitations. One of the reasons for this is that it was the sheer number of translations that were being published that concerned the regime, rather than a fear of what they might contain. But the regime viewed the publishers as a loyal and trustworthy group and did not want to apply damaging limitations. This would only change when anti-Semitic legislation would impose such a thorough purge of books that any hesitation the regime might have felt against damaging the publishers' interests would be swept aside - as we shall see shortly.

The first institutional measure that I have been able to find that specifically targeted translations was a circular that was sent in January 1937 to the publishers by the state censor (now upgraded to the Ministry for Popular Culture, henceforth, the Ministry), which required them to send a list of all new publications every month to the local Prefecture; to send a fourth copy of each book to the Ministry, on top of the three copies they were already obliged to send to the Prefecture so that their distribution could be authorized; and, significantly, to inform the Ministry beforehand each time the decision was made to translate a book. ${ }^{13}$ Not a particularly threatening move, but one which signalled a desire on the part of the Ministry to start keeping track of exactly how many books were being translated; and possibly to give the publishers the sense that they were being observed more closely. No further steps were taken until the following year when, in January 1938, the Ministry requested that publishers send a list of all the translations they had published so far, and all those that they planned to publish in the future. This already signalled a more ominous interest in the real figures concerning translations. ${ }^{14}$

By now, the regime was building up towards the introduction of official racism, which would be made law in November 1938, and each Ministry was already preparing itself for the new priorities that this legislation would impose. Just two months later, in March 1938, the Ministry for Popular Culture imposed a system of prior authorization for the distribution of all translations, a measure which the publishers had successfully deflected the year before, ${ }^{15}$ while in August 1938 Giuseppe Bottai, the Minister of Education, forced the publishers to purge all school textbooks by Jewish authors (Rundle, 2010, pp. 167-70). Although

\footnotetext{
${ }^{13}$ The circular was dated 30 January 1937. A copy can be found in ASMi, PMG I, b.716 'Rassegna Bibliograica. Elenco delle pubblicazioni'.

${ }^{14}$ The request was made via a telegram to the publishers from Gherardo Casini, head of the Books Division at the Ministry for Popular Culture. AME, SAM, 'Ministro della Cultura Popolare'.

${ }^{15}$ Circular No. 1135, 26 March 1938. ACS, MI, DGPS, DAGR, Massime, b. S4 103 A (provv.), f. S4 B5, 'Traduzione e diffusione nel Regno di opere di autori Stranieri'. Quoted in Fabre (1998, p. 32; 2007, pp. 27-8).
} 
Rundle, Christopher (2018) "Stemming the flood: the censorship of translated popular fiction in Fascist Italy", Perspectives. DOI: 10.1080/0907676X.2018.1444646. (CThis Author Accepted Manuscript (AAM) may not be copied or distributed in any shape or form without written permission from the author.

Bottai was not targeting translations, his intervention to 'protect' vulnerable school children from the potential harm of racially unsound books is comparable to the intervention that the Ministry for Popular Culture would later make to protect the vulnerable masses from the moral dangers of popular literature.

Then, in September 1938, the Minister for Popular Culture, Dino Alfieri, formed a Commission for the purging of books [Commissione per la bonifica libraria]. In a letter to Mussolini he explained the purpose of the commission as follows:

[to] establish precise criteria and determine the most suitable and efficient methods to achieve a complete review of Italian book production and that of foreign books translated into Italian. This review has become all the more necessary in view of the racial directions from above. ${ }^{16}$

However, although the commission was originally intended to also tackle translations, it actually concentrated on carrying out a thorough anti-Jewish purge (Fabre 1998, p. 174; Rundle, 2010, p. 173), which it achieved in just over a year - thanks to the collaboration of the publishers who decided that it would be politic to pre-empt the decisions of the commission and voluntarily withdraw over 900 books from circulation. ${ }^{17}$ In April 1940, Alessandro Pavolini, who had succeeded Alfieri as Minister for Popular Culture in October 1939, announced in a budget speech to the Chamber of Fasces and Corporations [Camera dei fasci e delle corporazioni] that the work of the commission was complete and that nearly 1500 works had been banned (Rundle, 2010, p. 178). Although a few works were banned for moral or ideological reasons, the vast majority were banned because they were written by Jewish authors. Eventually, in March 1942, the Ministry also drew up a list of over 900 'unwelcome' [non graditi] authors, most of which were Jewish (Fabre, 1998, p. 3).

\section{(iii) Measures against translations and popular fiction coincide}

With the anti-Jewish purge now complete, the Minister Pavolini could turn his attention to translations. Official racism had introduced a state of general alarm into the public debate on books which had been absent up until 1938. The earlier, more detached attitude of the Ministry now gave way to the imperative of protecting the nation from the dangers, first of racial pollution in books, and then of the moral and spiritual pollution being introduced via translations. Given that it was the masses that were the most vulnerable to this pollution, it was their reading matter that needed to be monitored particularly closely: namely, popular fiction. Furthermore, it was popular fiction that was feeding the embarrassing statistics on translation, a situation which Pavolini was determined to correct.

In October 1940 Pavolini announced that he intended to impose a quota of $10 \%$ on translations - thereby bringing the treatment of books in line with cinema and theatre where quotas on foreign productions were already in place. He informed the publishers that each of their houses would have to respect this restriction on the number of translations they could publish, but that it would only apply to "so-called "imaginative" works and popular fiction, and did not affect classics or scientific works' ${ }^{18}$ Understandably, the publishers objected strongly to such a severe limitation and they managed to put off the decision until the beginning of 1942 when a more lenient quota of $25 \%$ was imposed (Rundle, 2010, pp. 184-90, pp. 194-7). That

\footnotetext{
${ }^{16} \mathrm{ACS}, \mathrm{MCP}$, b. 56, 'Produzione libraria italiana e straniera tradotta in italiano. Revisione totale'.

17 The best account of this purge is Fabre (1998).

${ }^{18}$ From a report of a meeting between the Minister Pavolini and representatives of the Publishers Federation which took place 2 October 1940. Preserved in AME, SAM, 'Federazione nazionale fascista degli editori'.
} 
Rundle, Christopher (2018) "Stemming the flood: the censorship of translated popular fiction in Fascist Italy", Perspectives. DOI: 10.1080/0907676X.2018.1444646. (CThis Author Accepted Manuscript (AAM) may not be copied or distributed in any shape or form without written permission from the author.

popular fiction was the main target of this restriction is confirmed in a budget speech that the Minister Pavolini gave in May 1942. First he referred to the sheer size of the translation phenomenon by underlining that 'in a Nation which is destined for a natural spiritual autarky' foreign imports could only be allowed to make up a certain quota of Italian cultural production and that the open door policy of the Liberal age had been reversed; he then referred to the moral dangers posed by translations saying that 'the Ministry had introduced particularly drastic limitations against crime fiction', and concluded that

[t]ranslations, which are now allowed in the measure of one work translated for every four Italian originals, have once again become a secondary source of useful knowledge rather than a hasty and invasive distortion of values. ${ }^{19}$

But, despite the apparent intransigence of his official statements, Pavolini remained ambivalent. On the one hand he was keen to abandon the lenient approach that the Ministry had so far adopted with the publishers and no longer showed the same reluctance to impose even quite damaging limitations on them; on the other, he was eventually persuaded to adopt a less severe quota - and that after a delay of over a year.

As the issue of the translation quota evolved, the Ministry also started to tighten the screws in other ways. A series of restrictions were introduced on serialized and magazine format novels that were designed, essentially, to make translated popular fiction, and crime fiction in particular, less readily available to the masses - without stretching to an all-out ban.

In December 1940 the Ministry wrote to the publisher Arnoldo Mondadori and informed him that he could no longer persist in sending in lists of translations that were incomplete. This was a reference to the January 1937 circular mentioned earlier that required publishers to send a list of all new publications every month. In order to minimize the impact of his house's translation statistics, Mondadori had been systematically omitting his most prolific series, such as the Libri gialli and Gialli economici crime series, and the Romanzi della palma series of popular novels, with the excuse that they were just "ephemeral periodical publications" - i.e. they were sold in cheap serialized or magazine format. ${ }^{20}$ By exploiting this contrived loophole, Mondadori was excluding literally hundreds of translations from his lists (Rundle, 2010, pp. 145-6, p. 226).

What is significant here is that the Ministry had clearly been aware of this but had allowed him to persist in exploiting this loophole for nearly three years, also allowing him to publish these novels without the required prior authorization. Now, with Pavolini's new determination to tackle the translation question more decisively, such flexibility was no longer appropriate. Instead the Ministry moved to monitor the popular and crime fiction market more closely and introduced a series of measures that would make it progressively more difficult for the masses to access this kind of literature.

First, in March 1941, it formalized the requirement that prior permission also be sought for all serialized novels. ${ }^{21}$ Then, in July, the Ministry forbad 'the publication of crime fiction in either periodical or magazine format', a move which effectively made it more difficult for the masses to buy crime fiction as it was now

\footnotetext{
${ }^{19}$ The speech was given to the Chamber of Deputies Commission and is reported in Giornale della libreria 55(19), 20 May 1942, p. 77. Note that Pavolini exaggerates the severity of the quota which he reports as $20 \%$ instead of $25 \%$.

${ }^{20}$ From a letter written by Mondadori to Gherardo Casini, dated 18 January 1938. AME, SAM, 'Minstero Cultura Popolare', Busta 65-66.

${ }^{21}$ Reported in Giornale della libreria 54(9), 1 March 1941.
} 
Rundle, Christopher (2018) "Stemming the flood: the censorship of translated popular fiction in Fascist Italy", Perspectives. DOI: 10.1080/0907676X.2018.1444646. (CThis Author Accepted Manuscript (AAM) may not be copied or distributed in any shape or form without written permission from the author.

available only in more expensive book format. ${ }^{22}$ Furthermore, in August, it imposed a specific system of prior authorization on all crime fiction "with a view to maintaining a more effective control over crime novels, both Italian and in translation'. ${ }^{23}$

Finally, in October 1941, the Ministry decreed that only those publishing houses that had already published crime novels could continue to do so; and that only at the rate of one novel per month, and at a minimum price of 5 Lire - a price bracket that was deliberately set 2-3 lire higher than the standard price of serialized novels. ${ }^{24}$ It is hard to gauge the general effects of this last restriction, but Mondadori, the publisher who had pioneered crime fiction in Italy, published no more crime novels after this date. And crime fiction was finally banned all together in April 1943, just three months before the collapse of the regime, officially because of a shortage of paper. ${ }^{25}$

Although the restrictions on serialized novels and crime fiction detailed above did not target translation specifically, there is little doubt that these genres were widely identified as one of the symptoms of the 'translation invasion'. Translations drove the market for popular fiction in Italy in the 1930s and when the regime intervened against popular fiction it was, in effect, intervening against translations as well.

\section{Conclusion}

One of Fascism's great ambitions was to succeed in creating a recognizably Fascist culture, and this ambition was felt just as strongly in the literary field as it was in the other arts. There was continual debate amongst the intellectual elite on how this objective could be achieved, most of which took place in the countless literary journals that were published at the time. Those with a more nationalist outlook felt that this new Fascist culture could only be found by Italy rediscovering its own cultural roots; roots that could be evoked either by recalling the glories of ancient Rome (though this was more the basis of Fascist iconography and ritual than a literary aesthetic) or by exalting the values of a simple rural life that was a conscious rejection of the perceived decadence of contemporary urban society and of international cosmopolitan culture. Theirs was an aesthetic that was inspired by Fascism's origins in regional squadrismo and was generally hostile towards the foreign. ${ }^{26}$ But Fascism was an eclectic movement, and it also included those who with equal conviction felt that a genuinely new Fascist culture, one that might even cultivate universal ambitions, could only emerge from fruitful exchange with other cultures and who looked to a modernist and cosmopolitan aesthetic. These were also years in which popular forms of culture, whose importance had been growing since the second half of the nineteenth century, began to seriously impose a change in perspective; a change that was met with much resistance by the cultural establishment. First via Weimar Germany and then via Hollywood, cinema was having an increasingly significant impact, both economically and culturally. In publishing, the social changes brought about by the Great War had accelerated the rise of a new readership that had a seemingly insatiable appetite for light reading, what in Italian they call letteratura di consumo, a phrase that captures the role of popular literature as a commodity to be bought and consumed like any other product. For many of the writers and intellectuals who came of age before WWI these changes were difficult to accept and adjust to. But for the regime, with its

\footnotetext{
${ }^{22}$ Circular No. 7286, dated 5 July 1941, reported in Giornale della libreria 54(29-30), 26 July 1941, p. 128.

${ }^{23}$ Circular No. 7743, dated 2 August 1941, reported in Giornale della libreria 54(33-34), 23 August 1941, p. 134.

${ }^{24}$ Reported in Giornale della libreria 54(43), 25 October 1941, p. 166.

${ }^{25}$ Reported in Giornale della libreria 56(17), 10 May 1943, p. 52. For further details see Rundle (2010, pp. 182-97).

${ }^{26}$ The Squadristi were the Fascist militias whose violence helped bring Mussolini to power in 1922.
} 
Rundle, Christopher (2018) "Stemming the flood: the censorship of translated popular fiction in Fascist Italy", Perspectives. DOI: 10.1080/0907676X.2018.1444646. (CThis Author Accepted Manuscript (AAM) may not be copied or distributed in any shape or form without written permission from the author.

paternalistic ambitions of moulding the Italian people into a new, more virile and martial race, popular culture was potentially a great opportunity, a tool with which to manipulate the masses. The problem for the regime was how to create a popular culture that could appeal to the masses and also retain the core values of Fascism. In this project, one could argue that the regime was overtaken by circumstances that were beyond its control. Despite all the energy spent monitoring and censoring everything that Italians could read, watch or hear; despite launching a colonial expedition that was intended to raise Italy to the status of world power but which proved an economic and political disaster; the Italians stubbornly refused to become the military race that Mussolini dreamed of, and to be drawn away from the cultural myths that they were creating for themselves: Weimar Germany first, and then contemporary America second, and the glamorous, decadent lifestyles they represented.

Translation runs like a fault line through this context; revealing the failures of the Fascist cultural project and the inadequacies of the regime. It was the fissure through which the irresistible appeal of the modern and the contemporary seeped into Italian society and slowly undermined any potential for genuine renewal that the Fascist revolution may have succeeded in accumulating in its early years. Translation was also a reflection of Fascism's interaction with the rest of the world, one in which it was forced to recognize the image of its own failure. The most violent critics of the translation industry, like Marinetti, must have sensed this. And however, ridiculous and short-sighted their nationalist and xenophobic fears can seem to us now, it is worth remembering that from their point of view, all their worst fears concerning translation were, in fact, realised.

\section{Abbreviations}

\section{Archives:}

ACS Archivio centrale dello stato, Rome

AME Archivio Storico Arnoldo Mondadori Editore, Fondazione Arnoldo e Alberto Mondadori, Milan

ASMi Archivio di stato, Milan

DRPT Digital Repository of the Politecnico di Torino

URL: http://digit.biblio.polito.it/3351/

\section{Collections within archives:}

DAGR Divisione affari generali e riservati

DGPS Direzione generale pubblica sicurezza

SAM Sezione Arnoldo Mondadori

MCP Ministero della cultura popolare

MI Ministero degli interni

PMG I Prefettura di Milano, Gabinetto - I serie

PMG II Prefettura di Milano, Gabinetto - II serie

\section{References}

Barrale, N. (2012). Le traduzioni di narrativa tedesca durante il fascismo [Translated German fiction during Fascism]. Roma: Carocci.

Barrale, N. (2015). Suicidio e autocensura nelle traduzioni italiane dei Frauenromane [Suicide and selfcensorship in the Italian translations of the Frauenromane]. Between Journal 5(9). DOI: http://dx.doi.org/10.13125/2039-6597/1578

Billiani, F. (2007). Culture nazionali e narrazioni straniere. Italia, 1903-1943 [National cultures and foreign narrations. Italy, 1903-1943]. Firenze: Le Lettere. 
Rundle, Christopher (2018) "Stemming the flood: the censorship of translated popular fiction in Fascist Italy", Perspectives. DOI: 10.1080/0907676X.2018.1444646. (CThis Author Accepted Manuscript (AAM) may not be copied or distributed in any shape or form without written permission from the author.

Bonsaver, G. (2007). Censorship and literature in Fascist Italy. Toronto: University of Toronto Press.

Bonsaver, G. \& Gordon, R. (eds.) (2005). Culture, censorship and the state in twentieth-century Italy. London: Legenda.

Bottai, G. (1937). Il libro e la cultura del popolo [Books and the culture of the people]. Critica Fascista, 1 July.

Ciarlantini, F. (1938). Il problema della razza e l'autarchia spirituale [Spiritual autarky and the problem of race]. Giornale della libreria 51(37-38), 253-254.

Decleva, E. (1993). Arnoldo Mondadori. Torino: UTET.

Dunnett, J. (2002). Foreign literature in Fascist Italy: Circulation and censorship. In TTR: traduction, terminologie, rédaction, 15(2), 97-123. DOI: http://dx.doi.org/10.7202/007480ar

Fabre, G. (1998). L'Elenco. Censura fascista, editoria e autori ebrei [The list. Fascist censorship, publishing and Jewish authors]. Torino: Silvano Zamorani editore.

Fabre, G. (2007). Fascism, censorship and translation. In F. Billiani (Ed.), Modes of censorship and translation (pp. 27-59). Manchester: St Jerome.

Gadducci, F., L. Gori \& S. Lama (2011). Eccetto Topolino. Lo scontro culturale tra fascismo e fumetti [Except Mickey Mouse. The cultural conflict between Fascism and comics]. Roma: Nicola Pesce Editore.

Mangoni, L. (1974). L'interventismo della cultura [Cultural interventionism]. Bari: Laterza.

Marrubini, C. (1938). Autarchia Editoriale [Publishing autarky]. Giornale della libreria LI - No. 3, 15 Jan $1938,17-18$.

Nottola, F. (2012). Realistic escapism: I Romanzi della Palma and feminine modernity in Fascist Italy (Unpublished doctoral thesis). University of Manchester, UK.

Pedullà, G. (1997). Gli anni del fascismo: imprenditoria privata e intervento statale [The years of Fascism: private enterprise and state intervention]. In G. Turi (Ed.), Storia dell'editoria nell'Italia contemporanea [History of publishing in contemporary Italy] (pp. 341-382). Firenze: Giunti.

Rubino, L. M. (2002). I mille demoni della modernità. L'immagine della Germania e la ricezione della narrativa tedesca contemporanea in Italia tra le due guerre [The thousand demons of modernity. The image of Germany and the reception of contemporary German fiction in Italy between the two wars]. Palermo: Flaccovio Editore.

Rundle, C. (2000). The censorship of translations in Fascist Italy. The Translator 6(1), 67-86. DOI: https://doi.org/10.1080/13556509.2000.10799056

Rundle, C. (2010). Publishing translations in Fascist Italy. Oxford: Peter Lang.

Santoni, L. (2010). Critica Fascista e il dibattito sulla traduzione (1935-1940) [Critica Fascista and the debate on translaion (1935-1940)] (Unpublished thesis). University of Bologna, Italy.

Tranfaglia, N., \& Vittoria, A. (2000). Storia degli editori italiani. Dall'Unità alla fine degli anni Sessanta [History of Italian publishers. From the Unification to the end of the Sixties]. Rome and Bari: Laterza.

Talbot, G. (2007). Censorship in Fascist Italy, 1922-43. Basingstoke and New York: Palgrave Macmillan. 